Historic, Archive Document

Do not assume content reflects current scientific knowledge, policies, or practices. 



\section{PRICE LIST OF PECAN TREES 1925-26}

\section{B. W. Stone = Thomasville, Ga.}

Terms 14 Cash With Order, Balance When Trees Are Ordered Shipped.

\begin{tabular}{|c|c|c|c|}
\hline & Each & 10 & 100 \\
\hline 2 to $3 \mathrm{ft}$ & $\$ 90$ & $\$ 800$ & 7000 \\
\hline 3 to $4 \mathrm{ft}$ & 100 & 900 & 8000 \\
\hline 4 to $5 \mathrm{ft} \ldots . . . . . . . . . .$. & 115 & $10 \cong 0$ & 9000 \\
\hline 5 to $6 \mathrm{ft}$ & 130 & 1100 & 10000 \\
\hline 6 tn $7 \mathrm{ft} . \ldots \ldots \ldots$ & 150 & 1200 & 11000 \\
\hline 7 to $8 \mathrm{ft}$ & 170 & 1400 & 13000 \\
\hline $81010 \mathrm{ft}$ & 190 & 1650 & 15500 \\
\hline
\end{tabular}

Height of tree measured from ground.

VARIETIES-Scbley, Stuart, Success, Moneymaker, Pabst, Mobile and

Frotscher.

No charges for packing and drayage.

Write for "The Pecan Business for Pro fit and Pleasure"-free. Send three good names of friends wanting booklet. 


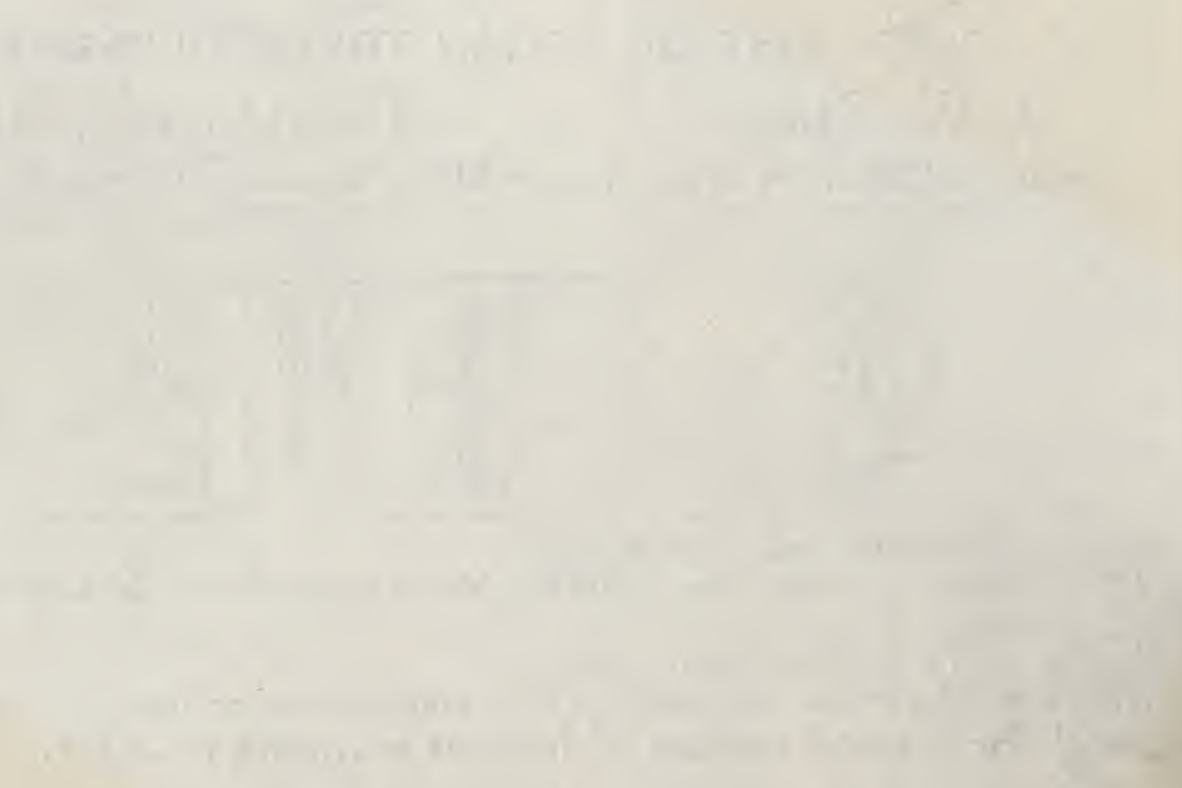

